\title{
Lizard meal as protein source enhanced broiler growth and reduced cost of production in Ishiagu, Ivo Local Government Area, Ebonyi State, Nigeria
}

'Olabode, A. D., ${ }^{2}$ Ugwuowo, L. C., ${ }^{3}$ Agu, C. I. and ${ }^{1}$ Ojuoloruntaye, T. J.

${ }^{1}$ Federal College of Agriculture, Ishiagu, Ebonyi state.

${ }^{2}$ University of Nigeria,Nsukka, Enugu state.

${ }^{3}$ Enugu state polytechnic, Iwollo Ezeagu L.G.A, Enugu State. E-mail:- Adeoladavid2005@yahoo.com: 08063379970

\section{Abstract}

The research work was carried out to ascertain the performance and cost benefits of broiler starter birds fed replacement levels of lizard meal to fish meal at starter phase. A total number of 90 day old Anak 2000 broiler chicks were used for the experiment. The birds were assigned to five treatment group of eighteen birds each been replicated thrice with six birds per replicate. Lizard meal was included to replace fish meal at levels of 0, 25, 50, 75 and 100\% respectively. Feed and water were given ad-libitum. Birds fed $75 \%$ inclusion levels of lizard meal (treatment 4) to replace fish meal was superior to birds in other treatments in terms of average final body weight, average daily feed intake, average weight gain and feed conversion ratio. Cost benefit analysis also showed that birds in treatment 4 (75\% lizard meal inclusion) was better than the rest of the treatment group.

Keywords: Performance, cost benefit, broiler starter, lizard meal, fish meal.

\section{Introduction}

It is a known fact that human population in Nigeria is on the increase, while food production is declining. This had led to food shortage especially animal protein (Olabode, 2015), which has resulted in serious malnutrition mostly among children and adolescents. An average Nigerian consumes about $7 \%$ of animal protein daily as against the minimum requirement of $28 \mathrm{~g}$ per short fall of $75 \%$ (Ahaotu and Ekanem, 2009). A very urgent task facing the world is that of providing sufficient food of adequate quantity and quality for the rapidly increasing human population. The food deficiency situation is more serious with protein deficiency of calories and microelements (Olabode, 2008). However, it has been stated that poultry production holds the key for bridging the gap of animal protein consumption in the Nigerian population. Poultry as a source of protein supply white meat and eggs which is high in protein and nutrient values. Although the high cost of poultry feed has been traced to the competition between human and poultry for the use of conventional feed ingredients such as fish meal, hence the need to substitute this high cost conventional feed ingredient with a low cost potential feed ingredient like lizard meal. Agama agama is a species of lizard from the Agamidae, mostly found in the sub-saharan Africa region. They are usually distinguished from amphibians by their dry, scarly skin that limits water lose, more powerful jaws, internally fertilize, and advanced circulatory, respiratory, excretory, nerves system and considerable behavioral control over their body temperature (Miller and Harley, 1996). Agama lizards are of different types and occur in different sizes. They usually live in groups or colonies. The lizard has a head and a trunk that are joined by a definite neck with a long tapering tail. They live in walls and ceiling of buildings and feed on small insects by picking them on tips of their sticky tongues. 
Lizard meal as protein source enhanced broiler growth and reduced cost of production

\section{Materials and methods}

The research work was carried out at the poultry unit of the Animal Production Department, Federal College of Agriculture, Ishiagu, Ebonyi State. Mature male and female Agama agama lizards were caught at the Federal College of Agriculture, Ishiagu campus by hunting. Care was taken to avoid much damage to the carcass. The lizards were slaughtered and the internal organs removed. The carcass was boiled at $100^{\circ} \mathrm{C}$ for five minutes and thereafter sundried to appreciable moisture content. The sundried Agama agama lizard carcass was later ground into meal using the hammer mill and then incorporated into the diets of the birds according to the replacement levels appropriated to each treatment group.

Five experimental diets were formulated using replacement levels at 25\%, 50\%, $75 \%$ and $100 \%$ of lizard meal with fishmeal in treatments 2, 3, 4 and 5 respectively (as shown in Table 1). Treatment 1 served as the control with $0 \%$ level of lizard meal. The completely randomized design (CRD) was used. Ninety unsexed Anak 2000, four weeks old birds were used for the research work. Each treatment had eighteen birds with three replicates consisting of six birds per replicate. Feed and water were given $a d-$ libitum and vaccinations were given as at when due.

Initial weight of the birds were taken at the beginning of the study and then subsequently on a weekly basis as the difference between the quantity of feed given the previous day and the quantity that is left the next day. Feed conversion ratio was obtained as the ratio of feed intake divided by the weight gain. Data collected were subjected to analysis of variance (ANOVA) according to the procedure of Steel and Torrie (1990).Significantly different means were separated according to the method of Duncan multiple range test as outlined by Obi (2002). Proximate analysis of the lizard meal and the diets were carried out using the procedure of AOAC (2005).

Table 1: Composition of broiler starter diet on percentage dry matter basis

\begin{tabular}{llllll}
\hline & TI & T2 & T3 & T4 & T5 \\
\hline Ingredients & $(0 \%)$ & $(25 \%)$ & $(50 \%)$ & $(75 \%)$ & $(100 \%)$ \\
Fish meal & 3.50 & 2.63 & 1.75 & 0.87 & 0.00 \\
Lizard meal & 0.00 & 0.87 & 1.75 & 2.63 & 3.50 \\
TOTAL & 100 & 100 & 100 & 100 & 100 \\
\hline
\end{tabular}

Other feed ingredient had same value across treatment group: Maize $\quad \mathbf{- 5 4 . 0 0 ;}$ Wheat offal $\mathbf{- 5 . 0 0}$; Soybean meal-5.40; Groundnut cake-25.00; Blood meal-2.00; Bonemeal-2.50; Limestone-1.50; Salt0.25; Starter premix-0.35; Lysine-0.15; Methionine-0.35.

Table 2: Proximate composition of lizard meal

\begin{tabular}{ll}
\hline Components & Percentage \\
\hline Dry matter & 95.12 \\
Moisture & 4.88 \\
Crude protein & 53.62 \\
Crude fiber & 11.32 \\
Ether extracts & 1.84 \\
Ash & 10.16 \\
Nitrogen free extracts & 18.18 \\
\hline
\end{tabular}




\section{Olabode, Ugwuowo, Agu and Ojuoloruntaye}

\section{Results and discussion}

The proximate analysis of the lizard (Agama agama) meal is shown in Table 2. The results showed that the Agama agama lizard has a high crude protein content of $54.8 \%$, moderate crude fiber content of $11.32 \%$, ether extract content of $4.84 \%$, ash content of $10.16 \%$, nitrogen free extract of $13.98 \%$ and a low moisture content of $4.90 \%$ respectively. The results obtained in this present study showed similarity to that of the fish meal which had $60.04 \%$ crude protein, $7.63 \%$ crude fiber, $10.26 \%$ ash content, $9.80 \%$ ether extract, $9.01 \%$ nitrogen free extract and $3.26 \%$ moisture content. Results for proximate analysis of the lizard meal in the present study was in agreement with that reported by Abulude $e t$ al. (2007), where they obtained a range value of $54.05-57.69 \%$ level of crude protein, 2.56-3.01\% ether extract, 1.11$3.18 \%$ ash content, $21.38-21.94 \%$ nitrogen free extract and a moisture content of 3.85$4.18 \%$ respectively. However, it was lower than the value of $59.06-60.16 \%$ crude protein reported by Tiamiyu et al. (2014). Thus, the gap in the results of the analysis could be due to factors such as climatic differences in geographical location, available and type of feed materials available to the lizard itself. Also from the analysis of the lizard meal it can be derived that the lizard meal is superior when compared to other unconventional animal protein sources such as locust meal, grasshopper meal, silk worm caterpillar meal and maggot meal (Ogunji, 2004 and Olabode, 2008).

Table 3: Performance characteristics and economic analysis table

\begin{tabular}{|c|c|c|c|c|c|c|}
\hline \multirow[b]{2}{*}{ Parameters } & \multicolumn{4}{|c|}{ Treatments } & \multirow[b]{2}{*}{$\begin{array}{c}\text { T5 } \\
(100 \%)\end{array}$} & \multirow[b]{2}{*}{ SEM } \\
\hline & $\begin{array}{l}\text { T1 } \\
(0 \%)\end{array}$ & $\begin{array}{l}\text { T2 } \\
(25 \%)\end{array}$ & $\begin{array}{l}\text { T3 } \\
(50 \%)\end{array}$ & $\begin{array}{l}\text { T4 } \\
(75 \%)\end{array}$ & & \\
\hline Initial body weight (g/bird) & 357 & 362 & 360 & 358 & 360 & - \\
\hline Final body weight (g/bird) & $1444^{\mathrm{b}}$ & $1366^{\mathrm{c}}$ & $1350^{\mathrm{c}}$ & $1526^{\mathrm{a}}$ & $1268^{\mathrm{d}}$ & 29.35 \\
\hline Av.Daily feed intake (g/bird) & $103.94^{\mathrm{b}}$ & $105.92^{\mathrm{a}}$ & $98.19^{c}$ & $106.76^{a}$ & $103.84^{\mathrm{b}}$ & 1.62 \\
\hline Av.Daily Wt. gain (g/bird) & $51.76^{\mathrm{a}}$ & $47.68^{b}$ & $48.51^{\mathrm{b}}$ & $56.17^{\mathrm{a}}$ & $44.16^{\mathrm{c}}$ & 1.41 \\
\hline Feed conversion ratio & $2.01^{\mathrm{a}}$ & $2.22^{\mathrm{a}}$ & $2.02^{\mathrm{a}}$ & $1.90^{\mathrm{b}}$ & $2.35^{\mathrm{a}}$ & 0.05 \\
\hline Cost of DOC & 200 & 200 & 200 & 200 & 200 & - \\
\hline Cost of feed & 120.25 & 119.20 & 116.67 & 112.24 & 109.98 & 9.41 \\
\hline Miscellaneous Expenses & 195 & 195 & 195 & 195 & 195 & - \\
\hline Total Expenditure & 515.25 & 514.20 & 511.67 & 507.24 & 504.98 & 4.68 \\
\hline Income from sale of birds & $710^{\mathrm{b}}$ & $690^{\mathrm{b}}$ & $670^{\mathrm{b}}$ & $750^{\mathrm{a}}$ & $650^{c}$ & 2.90 \\
\hline Net profit & $194.75^{b}$ & $175.80^{\mathrm{b}}$ & $158.33^{c}$ & $242.76^{\mathrm{a}}$ & $145.02^{\mathrm{c}}$ & 11.23 \\
\hline
\end{tabular}

Effect of replacement levels of lizard meal to fish meal on the growth performance of the birds is shown in Table 3 . The results showed that birds fed diet 4 had the highest value of feed intake $(106.76 \mathrm{~g})$, which was significantly $(\mathrm{p}<0.05)$ higher than for birds fed diets 1,3 and 5 with values of $103.94 \mathrm{~g}$, $98.19 \mathrm{~g}$ and $103.84 \mathrm{~g}$, but similar to those fed diet 2 with value of $105.92 \mathrm{~g}$. This was similar to the work of Ojewole (2005), who compared the utilization of three animal protein sources by broiler chicken. Results for average daily weight gain showed that birds fed diet 4 and 5 with values of $56.17 \mathrm{~g}$ and $51.76 \mathrm{~g}$ had relatively higher values of average daily weight gain than those on diets 2, 3 and 5 with values of $47.68 \mathrm{~g}$, $48.51 \mathrm{~g}$ and $44.16 \mathrm{~g}$ respectively. This could be due to the absence of anti-nutritional factor in the lizard meal, thereby making the protein nutrient bio-available for the development of muscles and growth of the 


\section{Lizard meal as protein source enhanced broiler growth and reduced cost of production}

birds. This was similar to the report of Ijaiya and Eko (2009) who obtained a significant $(\mathrm{p}<0.05)$ effect when silk worm caterpillar meal was used to replace fishmeal in the diet of broiler birds. Feed conversion ratio for birds on diet 4 (1.90) was superior compared to the rest of the birds in other treatment group. Birds fed diet 5 (2.35) and 2 (2.22) were similar statistically. Also birds fed diet 1 (2.01) and 3 (2.02) were similar $(p>0.05)$ to themselves. Cost benefit analysis showed that treatment 4 (75\%LM) had better net profit margin of \#242.76, which was significantly $(\mathrm{p}<0.05)$ different from the rest of the treatments, namely T1 (\#194.75), T2 (\#175.80). T3 (\#158.33) and T5 (\#145.03).

\section{Conclusion}

From the data obtained from the research work, it can be concluded that replacement of fishmeal with lizard meal at the level of $75 \%$ was positive in terms of the parameters studied with no negative impact in terms of mortality.

\section{References}

Abulude, F. O., Adesanya, W. O., Ogunkoya, V. O. and Ajayi, E. 2007. Compositional studies on tropical species of Agama agama lizards. International journal of Zoological research 3 (4): 218222.

Ahaotu, E. O. and Ekanem, B. U. 2009. Replacement value of feather meal for fishmeal on the performance of finisher broiler chicks. International Journal of Tropical Agriculture and Food sip. 3 (3): 223-237.

AOAC 2005. Association of Official Analytical Chemists. Official methods of Analysis. $18^{\text {th }}$ edition. AOAC, Inc. Arlingon, Virginia,
USA.

Ijaiya, A. T. and Eko, E. O. 2009. Effect of replacing dietary fishmeal with silkmeal caterpillar meal (Anaphe infracta) on the performance, carcass characteristics and haematological parameters of finisher broiler chickens. Pakistan Journal of Nutrition. 8 (6): 850855.

Miller, S. A. and Harey, J. P. 1996. Zoology $3^{\text {rd }}$ Edn., WCB/MC Grawattill Company Inc. U.S.A. Pp: 395.

Obi, I. U. 2002. Statistical methods of detecting differences between treatment means and research methodology issue in laboratory and field experiments. A.P. Company ltd.

Ogunji, J. O. 2004. Alternative protein sources in diet for farmed tilapia. Animal Science.com review. No 13, Nutrition abstract and review, 74 (8): 23-32.

Ojewola, G. S and Annah, S. I. 2005. Nutritive and Economic value of Denish fishmeal, crayfish dust meal and shrimp meal in finishing broiler diet. African Journal; Biotech. 5: 19-25.

Olabode, A. D. 2008. The effect of supplemental neem (Azadirachta indica) leaf meal on the performance of broiler birds. An Msc research work submitted to the department of Animal Science. University of Nigeria, Nsukka, Enugu state. Pp 3-17.

Olabode, A. D. 2015. Performance, egg quality characteristics and serum biochemistry of laying birds fed diet containing neem leaf meal. A Ph.D thesis submitted to the Department of Animal Science, 
Olabode, Ugwuowo, Agu and Ojuoloruntaye

Faculty of Agriculture, University of Nigeria, Nsukka, Enugu State.

Tiamiyu, L. O. 2014. Proximate analysis of Agama agama lizard meal; Implication for fish nutrient. Octa. Journal of Bioscience international peer-reviewed journal. Vol.2(1):28-31.
Steel, R. G. D and Torrie, J. H. 1990. Principles and practice of statistics,

Received: 2nd September, 2017

Accepted: 30th November, 2017 